\title{
Analysis on the Construction Paths of Business Administration in the Digital Economy
}

\author{
Xi Heng ${ }^{\text {a, }}{ }^{*}$, Yan Wang ${ }^{b}$, Rui Wu ${ }^{c}$ \\ Xi'an Eurasia University, Xi'an, China \\ a, * hengxi@eurasia.edu, b wangyan@eurasia.edu, c wurui@eurasia.edu
}

\begin{abstract}
In order to face the changes in the era of digital economy, the business administration major needs to carry out digital transformation, considering the rise of digital technology and industrial changes. This paper firstly introduces the direction of the business administration major in the digital economy era. Secondly it conducts environmental analysis and stakeholder research, for the purpose of drawing the expectations and requirements for the development of business administration. In addition to the knowledge and skills of business management in the new era, business administration professionals also need to have knowledge and capabilities such as process management, business data analysis, and the use of digital technology. Based on formulating overall development goals, this paper puts forward the construction paths from 8 aspects, including admissions and employment, professional features, courses and teaching materials, faculty, research, practical teaching and Industry-university cooperation, local internationalization, and quality assurance.
\end{abstract}

Keywords: Digital Economy; Business Administration; Development Goals; Construction Paths.

\section{Introduction}

Business administration is one of the common business majors in China. Almost one-third of undergraduate colleges and universities offer this major. Compared with other business majors, business administration is more comprehensive and comprehensive, and emphasizes the cultivation of students' knowledge, ability and accomplishment in business management activities. Corporate management is facing new challenges in the era of digital economy, with the development of technologies such as big data, cloud computing, artificial intelligence, blockchain, and the Internet of Things. In the past, corporate management often relied on the personal experience of managers. But now, corporate management emphasizes data governance and intelligent management, because the value of data is becoming more prominent. The changes of the times are forcing the business administration to carry out digital transformation.

\section{Business Administration in the Digital Economy}

Digital economy era has shown new product forms, organizational forms, business models, economic paradigms and business rules, that is different from the production method of tangible material products in the industrial economy era. The rise of new technologies and industrial changes affect the organization's business activities and management, which will inevitably change the organization's business behaviour and business ecosystem, and put forward new requirements for existing business education [1]. In the era of digital economy, the main directions of business administration include: enterprise digital operation (Xi'an Eurasia University, Xi'an, China, undergraduate), digital operation and management (Brest Business School, France, master), digital marketing (Harbin Institute of Technology, Weihai, China, undergraduate) and so on. Taking Xi'an Eurasia University as an example, the business administration major aims to cultivate applied talents who can engage in business management activities in industrial and commercial enterprises and other organizations in the digital economy. Students at school have a systemic grasp of management, economics, data science and other related knowledge, receive modern enterprise digital operation and management training, and have professional capabilities such as digital management, business operations, and business data analysis. With high-quality employment as the orientation, the school 
designs a "platform + hierarchical" training structure, and provides different graduation-oriented curriculum packages, workshops and second classroom design according to the individual needs of students. In addition, the curriculum system highlights the integration of business management and modern technology, which has dedicated digital module courses. Furthermore, in order to improve students' knowledge application and real practical ability, practical teaching is organically integrated into the professional teaching system, and the curriculum adopts a model that combines theory and practice. In terms of specific curriculum settings, courses such as process management, digital customer management, digital marketing, and digital business management practice can be offered to enhance students' cognition and related skills of digital management.

\section{Environmental Scanning and Stakeholder Analysis}

During the construction of the business administration major, it is necessary to strictly abide by national policies, closely integrate with industry development trends, make commitments to stakeholders, focus on the shaping of professional characteristics and the improvement of brand influence. On this basis, it pays attention to the development of benchmarking and similar universities, which to find out our own positioning and development characteristics. Take the business administration major of Xi'an Eurasia University as an example, the paper analyses the environment and stakeholders of major construction.

\subsection{Policy Orientation}

The Fifth Plenary Session of the 19th Central Committee proposed to accelerate the development of a modern industrial system and promote the optimization and upgrading of the economic system. Adhere to the focus of economic development on the real economy, unswervingly build a manufacturing power, a quality power, a network power, and a digital China, advance the advanced industrial base, modernize the industrial chain, and improve economic quality and core competitiveness. It is necessary to improve the modernization level of the industrial chain and supply chain, develop strategic emerging industries, accelerate the development of modern service industries, coordinate the advancement of infrastructure construction, accelerate the construction of a transportation power, advance the energy revolution, and accelerate the development of digitalization [2].

"Xi'an Modern Industrial Layout Plan" pointed out that vigorously implement the advanced manufacturing strategy to strengthen the city, aiming at the "top five", comprehensively improve the industrial energy level and core competitiveness, clarify the focus of industrial development as the main line, and focus on the industrial layout and platform. Focus on construction and policy support, focus on promoting the growth of the " $6+5+6+1 "$ modern industrial system with distinctive characteristics, reasonable layout and agglomeration of elements, and build "four beams and eight pillars" that support high-quality economic development. By 2025, the city's total output value of the advanced manufacturing industry above designated size will exceed RMB 1,000 billion, accounting for $70 \%$ of the industry above designated size [3].

Focusing on manufacturing power, quality power, network power, and digital China, the business administration major has shifted its development focus to service-oriented manufacturing, quality construction, standardization construction, process management, and digital operations. Currently, it has Xi'an Quality Management Research Institute and Service-oriented Manufacturing Research Institute to help the major digital transformation in Xi'an Eurasia University.

\subsection{Stakeholder Analysis}

\subsubsection{National Supervision}

It is necessary to comply with the "National Standards for the Teaching Quality of Business Administration Majors of the Ministry of Education" during the construction of the business administration major. Encourage the development of emerging cross-disciplinary courses, explore 
the establishment of a new mechanism for cross-faculty, cross-disciplinary, and cross-professional training of innovative and entrepreneurial talents, and promote the transformation of talent training from a single type of discipline to a multi-disciplinary integration type. In addition, pay attention to the introduction of inter-university curriculum resources, social resources, foreign high-quality educational resources and network resources, to provide students with high-quality courses and convenient conditions for independent learning. Make full use of various innovative and entrepreneurial education and practice platforms, and actively carry out innovative and entrepreneurial practice activities. Hire personnel with practical experience from their respective fields to take part of the teaching tasks, and encourage the hiring of well-known scientists, successful entrepreneurs, entrepreneurs, venture capitalists and other outstanding talents from all walks of life to teach or instruct teachers in professional courses. Establish a quality assurance target system, which is effectively reflected, implemented and implemented in the training plan, training process, and training results, and improves graduate satisfaction and employer recognition [4].

\subsubsection{School Strategy}

According to "Future Strategic Thinking of Business Construction under the Digital Intelligence Economy in Xi'an Eurasia University ", the College of Business Administration, as the basic college of the business branch, will undertake to provide high-quality platform courses for large business subjects, help business students to be admitted to graduate students at home and abroad, and establish a business case centre. As the core and basic major of the College of Business Administration, the business administration major, based on the current resources and future development positioning of the major, needs to shoulder the responsibility of building a high-quality platform for large business courses. In addition, with the help of the bilingual experimental class of business administration, we will provide international guidance for business students. With the advantages of the research institute, we will build a case database for local SMEs in Xi'an. As the bridgehead of the school's digital transformation, the business administration major will fully serve the school's digital transformation, and do a good job in process management and quality monitoring for the school's digital transformation.

\subsubsection{Student Expectations}

Focusing on students' expectations for professional construction and future development, questionnaire surveys and interviews were conducted with students and graduates respectively. The following main conclusions were drawn.

Among the students, the freshmen pay attention to the cultivation of entrepreneurship and personnel administrative skills, and the senior students pay attention to the improvement of overall abilities, in which the data analysis and project management skills have increased significantly compared with the freshmen. The employment fields that students expect are mainly concentrated in industrial manufacturing, wholesale and retail, and new Internet companies.

$71 \%$ of the graduates choose to work in Shaanxi, and $82 \%$ of them choose to stay in Xi'an. Indepth cooperation with local enterprises in $\mathrm{Xi}^{\prime}$ an is the focus of professional construction. In addition, the "MYCOS, Evaluation Report on the Training Quality of 2019 Graduates of Xi'an Eurasia University" shows that the TOP3 important basic abilities of graduates are coordination arrangements, active listening and persuading others, and the TOP3 core knowledge are psychology, human resources, and marketing. Through Industry-university projects, subject competitions, and student activities, etc., students must be cultivated to coordinate arrangements, communication and expression skills. More, we integrate psychology-related knowledge into professional curriculum teaching, and build optional curriculum packages for human resources and marketing.

\subsubsection{Business Expectations}

Through questionnaire surveys of companies and data crawling on recruitment websites, the key abilities of business administration graduates are extracted, and it is concluded that graduates should have communication, planning, good writing, internationalization, fast learning, teamwork, data 
analysis, innovative thinking, leadership potential, clear logic, emotional control, stress management, positive optimism, independent thinking and other basic qualities. In addition, companies pay attention to the experience of students when recruiting new students, including corporate internship experience, social practice experience, school club activity experience and student cadre experience. This requires us to conduct in-depth cooperation with digital pioneers, such as Ding Talk, Yeahmobi and other well-known companies.

\subsubsection{Summary and Thoughts}

Through the analysis of stakeholders and environment, the business administration major needs to take the "National Standard" as the bottom line, and strictly require all tasks of professional construction with high standards such as First-class majors, First-class courses, First-class teachers, and First-class teaching materials. Based on the school strategy and branch strategy development requirements, the business administration major needs to actively carry out digital transformation. We drive high-quality employment through high-quality internships, which provide high-quality education for school students, and which provide continuous learning opportunities for graduates. Teachers can focus on teaching and scientific research, leading students to participate in subject competitions and industry-academic projects, etc. We attach importance to the cultivation of students' comprehensive quality, interdisciplinary ability cultivation and practical project experience, etc., to train students to be able to master multiple skills.

\subsection{College and University Analysis}

\subsubsection{Analysis of Foreign Benchmark Universities}

The course team surveyed 15 well-known foreign universities, including Hult International Business School, MIT Sloan School of Management, EMLYON Business School, Montpellier Business School, etc. The survey results showed that:

- Focus on international certification.

- Emphasize the cultivation of applied talents through interdisciplinary integration.

- Introduce industry certificate training.

- Attach importance to the cooperative relationship with the company.

- Pay attention to the training of students' data ability and offer related courses, such as digital business, business innovation in the digital age, data analysis and visualization, digital media marketing, business analysis based on $\mathrm{R}$ language.

\subsubsection{Analysis of Domestic Benchmark Universities}

The survey was conducted on 46 domestic colleges and universities, based on China's fourth round of business management discipline assessment, the alumni association China university of finance and economics ranking, and Shaanxi Province's universities which have business administration major. Through analysis of domestic benchmark universities, such as Renmin University of China, Xi'an Jiaotong University, Central University of Finance and Economics, etc., the survey results are as follows:

- Enrolment trend is in accordance with the first-level catalogue of business administration.

- Relying on superior disciplines and resources to run schools.

- Attach importance to the integration of multiple disciplines, and emphasize the application of artificial intelligence and big data technology in management.

- Focus on in-depth integration of production, education and research.

- Offer a business administration minor or double degree program for non-management students. 


\subsubsection{Analysis of Similar Universities}

Similar universities include Xi'an International Studies University and Xi'an International University, etc. First, Xi'an International Studies University highlights the advantages of English in the construction of majors, and uses bilingual teaching for core courses. In addition, it pays attention to case teaching, highlighting regional characteristics and international elements when selecting cases. Second, Xi'an International University emphasizes "professional + entrepreneurship" in the professional construction, which emphasizes the application of "localized case" teaching and online teaching, and there are also excellent entrepreneurs entering the classroom.

\subsubsection{Summary and Thoughts}

The following six points are summarized through the analysis of domestic and foreign universities.

- Highlight the application-oriented orientation of running a school, by emphasizing practical teaching.

- Relying on the advantages of big data governance and business data analysis, to highlight "management + technology" and "digital + process".

- Carry out international certification cantering on the EPAS international business certification system.

- Introduce certificate courses, including skills certificates, class hours certificates and honour certificates.

- Establish a school-level, provincial, national, and world-level subject competition system, following benchmark colleges and universities.

\section{Development Goals}

Development goals of the business administration major are formulated on the basis of environment scanning, the strategic requirements of the school, the First-class professional construction standards of Shaanxi Province, the EPAS international certification standards.

\subsection{Overall Goal}

Become a leader in the cultivation of applied talents for digital operation of enterprises in the western region, creating "management + technology" and "digital + process" professional characteristics, to cultivate high-quality digital management talents for SMEs guided by First-class enterprise employment standards, focusing on the development needs of national digital economy, benchmarking provincial-level First-class professional construction standards and EPAS international certification standards.

The three main tasks of the business administration major in the next five years are building a First-class major in Shaanxi Province, passing international certification, and providing high-quality platform courses for the school's major business.

\subsection{Sub-objectives}

In order to ensure the smooth realization of the overall goal and three main tasks of the business administration major, the sub-projects were formulated from two levels, namely quantitative and qualitative, from 8 aspects that respectively are admissions and employment, professional features, courses and teaching materials, faculty, research, practical teaching and Industry-university cooperation, local internationalization, and quality assurance. See Table 1 for details. 
Table 1. Sub-objectives of Business Administration

\begin{tabular}{|c|c|c|}
\hline Sub Option & Quantitative Indicators & Qualitative Indicators \\
\hline Admissions and employment & $\begin{array}{c}\text { a. First choice online rate } \\
\geq 150 \% \\
\text { b. One-time employment rate } \\
\geq 95 \% \\
\text { c. Employment satisfaction } \\
\geq 85 \% \\
\text { d. Employment in TOP } \\
\text { companies } \geq 40 \% \\
\text { e. Going to higher education at } \\
\text { home and abroad } \geq 25 \%\end{array}$ & $\begin{array}{l}\text { a. Steady increase in first choice rate. } \\
\text { b. Admission scores increase year by year. } \\
\text { c. The level of employment continues to } \\
\text { improve. } \\
\text { d. Student employment satisfaction has } \\
\text { steadily improved. }\end{array}$ \\
\hline Professional features & Professional brand $\geq 3$ & $\begin{array}{l}\text { Reach the leading level in the western region, } \\
\text { focus on the cultivation of capabilities in } \\
\text { digital operation, process management, and } \\
\text { business data analysis. }\end{array}$ \\
\hline $\begin{array}{c}\text { Courses and teaching } \\
\text { materials }\end{array}$ & $\begin{array}{c}\text { a. Constructing courses } \\
\text { according to First-class } \\
\text { standards }=100 \% \\
\text { b. School-level key courses } \geq \\
4 \\
\text { c. Provincial First-class } \\
\text { undergraduate courses } \geq 2 \\
\text { d. National boutique online } \\
\text { open course } \geq 1 \\
\text { e. National First-class } \\
\text { undergraduate course } \geq 1 \\
\text { f. Textbook construction } \geq 1 \\
\text { book/year }\end{array}$ & $\begin{array}{l}\text { a. Curriculum system design is scientific and } \\
\text { reasonable. } \\
\text { b. Curriculum construction has plans, } \\
\text { standards, and measures. } \\
\text { c. Priority selection of teaching materials for } \\
\text { Marxist theory research and construction } \\
\text { project. }\end{array}$ \\
\hline Faculty & $\begin{array}{c}\text { a. Professor ratio } \geq 50 \% \\
\text { b. Proportion of PhD degree } \geq \\
30 \% \\
\text { c. Provincial and ministerial- } \\
\text { level teaching achievement } \\
\text { awards } \geq 1 \\
\text { d. Provincial-level teaching } \\
\text { teacher or team } \geq 1\end{array}$ & $\begin{array}{l}\text { a. Build a team of academic consultants and } \\
\text { experts of "enterprise executives + well- } \\
\text { known university professors". } \\
\text { b. Teachers' input in teaching practice is } \\
\text { guaranteed. } \\
\text { c. Have a teacher capacity improvement plan. }\end{array}$ \\
\hline Research & $\begin{array}{l}\text { a. National-level project } \\
\text { application } \geq 2 \text { items } \\
\text { b. Provincial and ministerial- } \\
\text { level scientific research } \\
\text { projects } \geq 2 \text { items/year } \\
\text { c. Department-level scientific } \\
\text { research projects } \geq 3 \\
\text { items/year } \\
\text { d. CSSCI papers } \geq 2 \\
\text { papers/year } \\
\text { e. Provincial scientific } \\
\text { research team } \geq 1 \\
\text { f. Students participating in } \\
\text { project research and } \\
\text { publishing papers } \geq 10 \%\end{array}$ & $\begin{array}{l}\text { a. Form a scientific research team. } \\
\text { b. Ensure teachers have a certain amount of } \\
\text { research time. } \\
\text { c. Teachers' scientific research ability and } \\
\text { quality will be steadily improved. }\end{array}$ \\
\hline $\begin{array}{l}\text { Practical teaching and } \\
\text { Industry-university } \\
\text { cooperation }\end{array}$ & $\begin{array}{l}\text { a. Sign a strategic agreement } \\
\text { with TOP companies } \geq 1 \text { per } \\
\text { year } \\
\text { b. Co-build internship bases } \\
\text { with industry enterprises } \geq 1 \\
\text { per year }\end{array}$ & $\begin{array}{l}\text { a. Normal operation of Xi'an Institute of } \\
\text { Quality Management. } \\
\text { b. Built Eurasia-DingTalk Virtual Simulation } \\
\text { Laboratory. } \\
\text { c. Established a service-oriented } \\
\text { manufacturing research institute. }\end{array}$ \\
\hline
\end{tabular}




\begin{tabular}{|c|c|c|}
\hline Sub Option & Quantitative Indicators & Qualitative Indicators \\
\hline & $\begin{array}{l}\text { c. Provincial-level virtual } \\
\text { simulation experiment } \\
\text { teaching center } \geq 1 \\
\text { d. Horizontal topics } \geq 4 \\
\text { items/year, with income not } \\
\quad \text { less than } 1 \text { million }\end{array}$ & $\begin{array}{l}\text { d. Give full play to the synergy of Industry- } \\
\text { university cooperation in talent training. } \\
\text { e. Develop high-quality employment } \\
\text { cooperative enterprises. }\end{array}$ \\
\hline Local internationalization & $\begin{array}{l}\text { a. Introduce international } \\
\text { projects } \geq 1 \text { item/year } \\
\text { b. Introduce foreign teachers } \\
\geq 1 \\
\text { c. All teachers have published } \\
\text { more than } 1 \text { English paper } \\
\text { d. Construction of bilingual } \\
\text { courses } \geq 2 \text { courses/year } \\
\text { e. The proportion of students } \\
\text { participating in international } \\
\text { projects } \geq 20 \%\end{array}$ & $\begin{array}{l}\text { a. Improve the teaching quality and visibility } \\
\text { of bilingual experimental classes. } \\
\text { b. Apply for ACBSP and EPAS international } \\
\text { certification. } \\
\text { c. Assist students in international education } \\
\text { and international employment. }\end{array}$ \\
\hline Quality assurance & $\begin{array}{l}\text { a. Stakeholder analysis report } \\
\quad \geq 1 \text { copy/year } \\
\text { b. Professional construction } \\
\text { quality report } \geq 1 \text { copy/year } \\
\text { c. Graduate follow-up research } \\
\quad \text { report } \geq 1 \text { copy/year }\end{array}$ & $\begin{array}{l}\text { a. Realize curriculum standardization. } \\
\text { b. Establish a professional internal monitoring } \\
\text { mechanism. } \\
\text { c. Improve graduate tracking mechanism. }\end{array}$ \\
\hline
\end{tabular}

\section{Construction Paths}

Construction paths are proposed respectively from the eight sub-projects in Table 1, in accordance with the overall goal and Sub-objectives, combined with the current situation of the business administration major.

\subsection{Admissions and Employment}

\subsubsection{Increase Professional Recognition Focus on Brand Building}

Further optimize the branch website and WeChat public account, increasing the number of professional introductions, professional activities, student growth, student role models and other tweets. At the same time, focus on improving the quality of tweets. And we should require every teacher to actively forward them, so that students can understand the profession to a greater extent, accept majors and are willing to promote business administration major.

Second, let students participate in the brand building of the branch, and actively contribute articles. Students are more willing to promote their own writing articles in the circle of friends, so that students and parents know more about the profession. In addition, it is necessary to increase the satisfaction of the students at school. Only when the students are satisfied can the students and their parents spread word-of-mouth on the major.

Third, encourage students to do volunteer services in the surrounding communities, so that residents can understand Xi'an Eurasia University and the business administration major. This will play a good role in publicity in terms of professional construction.

\subsubsection{Optimize Quality and Upgrade Levels of Employment}

First of all, we need to further strengthen school-enterprise cooperation and recommend students to practice in TOP companies. To promote high-quality employment for students through high-quality internships in TOP companies. Even if students may not be able to find employment in TOP companies in the future, they can recommend employment or direct employment in cooperative companies of TOP companies through the radiating and leading role of TOP companies. 
Second, we should build a practical certificate training system. After students have completed related courses such as ERP and digital platform practice, they can meet certain requirements and obtain recognition from companies such as SAP and DingTalk, which proves that students have acquired the corresponding professional skills. At the same time, students are encouraged to take professional related certificates, which can be used to replace corresponding course credits, such as senior digital manager certificates.

Third, employment workshops are carried out to provide students with workshops on resume production, employment positions and channels, interview skills, etc. In addition, the development of employability is implanted in the corresponding curriculum system, such as career planning, human resource management and other courses.

\subsection{Professional Features}

The professional direction of business administration is enterprise digital operation, focusing on enterprise digital operation, mainly engaged in teaching and research in digital operation and management, process management, business data analysis, etc., highlighting the characteristics of "management + technology" and "digital + process". At present, the current enrolment classes include 2 general classes and 1 bilingual experimental class. The training model is "professional teaching + project practice", "knowledge learning + scientific research + subject competitions", and "generalists + specialists".

Combining the characteristics of business, business administration students will serve as both a student and a career person after entering the school. As a career person, everyone is required to participate in the branch's Industry-university-research projects for improving their business literacy.

\subsection{Courses and Teaching Materials}

\subsubsection{Construct Courses According to First-class Standards}

Table 2. Classification of Core Courses of Business Administration

\begin{tabular}{|c|c|c|}
\hline Classification & Explanation & Representative Courses \\
\hline Online courses & $\begin{array}{l}\text { a. National boutique online open courses. } \\
\text { b. Build a Chinese MOOC brand. }\end{array}$ & $\begin{array}{l}\text { a. Enterprise Digital } \\
\text { Transformation } \\
\text { b. Digital Customer } \\
\text { Management }\end{array}$ \\
\hline Offline courses & $\begin{array}{l}\text { a. Face-to-face instruction. } \\
\text { b. Improve students' comprehensive ability. } \\
\text { c. Give full play to the role of the main battlefield of } \\
\text { classroom teaching. }\end{array}$ & $\begin{array}{l}\text { a. Business Ethics and } \\
\text { Regulations } \\
\text { b. Macro-economics } \\
\text { c. Business Office } \\
\text { Application Practice }\end{array}$ \\
\hline $\begin{array}{l}\text { Online and offline } \\
\text { mixed courses }\end{array}$ & $\begin{array}{l}\text { a. Make full use of national boutique online open courses. } \\
\text { b. Arrange } 20 \%-50 \% \text { of teaching time to implement students' } \\
\text { online autonomous learning. }\end{array}$ & $\begin{array}{l}\text { a. Management } \\
\text { b. Strategic Management } \\
\text { c. Marketing } \\
\text { d. Human Resource } \\
\text { e. Business English }\end{array}$ \\
\hline $\begin{array}{l}\text { Virtual simulation } \\
\text { experiment teaching } \\
\text { courses }\end{array}$ & $\begin{array}{c}\text { Solve the problems of lack of real experimental conditions, } \\
\text { involving high-risk or extreme environments, high costs, } \\
\text { high consumption, irreversible operations, large-scale } \\
\text { comprehensive training, etc. }\end{array}$ & $\begin{array}{c}\text { a. Business Thinking and } \\
\text { Case Practice } \\
\text { b. Business Operation } \\
\text { Simulation Practice } \\
\text { c. Digital Enterprise } \\
\text { Management Practice }\end{array}$ \\
\hline Social practice courses & $\begin{array}{l}\text { a. Through the "Youth Red Dream Building Journey", } \\
\text { "Internet +" College Student Innovation and } \\
\text { Entrepreneurship Competition, and social practice in } \\
\text { ideological and political theory courses, etc. } \\
\text { b. non-internship, practical training courses. }\end{array}$ & $\begin{array}{l}\text { a. Entrepreneurship } \\
\text { Management } \\
\text { b. Project Management } \\
\text { c. Market Research } \\
\text { Practice } \\
\text { d. Internet Business } \\
\text { Model Innovation }\end{array}$ \\
\hline
\end{tabular}


Combing with the business administration talent training program, we must build high standards for the curriculum, referring to the implementation opinions of the Ministry of Education for the construction of First-class undergraduate courses. See Table 2 for specific course categories.

\subsubsection{Integrate Curriculum and Subject Competition}

The learning results of some courses are directly used to participate in subject competitions, which are completed assessments in practical projects. For example, the final assignment of "Entrepreneurship Management" is used to participate in the "Internet +" college student innovation and entrepreneurship competition. Curriculum teaching is integrated with professional competitions, and competitions are used to promote teaching. Under the guidance of professional teachers, it comprehensively improves students' knowledge application ability, innovation ability, and cooperation ability [5]. Courses integrated competition and teaching are shown in table 3.

Table 3. Courses Integrated Competition and Teaching

\begin{tabular}{|c|c|c|c|}
\hline Course & Credit & Semester & Subject Competition \\
\hline $\begin{array}{c}\text { Business Thinking and Case } \\
\text { Practice }\end{array}$ & 3 & 2 & Global Management Challenge \\
\hline Market Research Practice & 2 & 4 & $\begin{array}{c}\text { "Zhengda Cup" National College Student Market } \\
\text { Survey and Analysis Competition }\end{array}$ \\
\hline $\begin{array}{c}\text { Digital Enterprise } \\
\text { Management Practice }\end{array}$ & 3 & 6 & $\begin{array}{c}\text { National University Student Information Skills } \\
\text { Competition }\end{array}$ \\
\hline $\begin{array}{c}\text { Business Operation } \\
\text { Simulation Practice }\end{array}$ & 3 & 7 & $\begin{array}{c}\text { National College Student Sand Table Simulation } \\
\text { Management Competition }\end{array}$ \\
\hline
\end{tabular}

\subsubsection{Implement the Integration of Teaching-Research-Case}

Teachers pay attention to the integration of "teaching-research-case" in the teaching process, transform scientific research results into teaching cases and apply them to teaching [6]. Relying on the Xi'an Quality Management Research Institute and the Small and Medium-sized Enterprise Case Research Centre, the "Xi'an Small and Medium-sized Enterprise Process Management Case Collection" was finally formed. Teachers use case teaching to introduce real business problems, and require students to come up with creative solutions.

\subsubsection{Prefer High-level Textbooks}

Priority selection of teaching materials for Marxist theory research and construction project. Currently, Marxist project textbooks have been selected for "Management", "Micro-economics", and "Macro-economics". And other courses have adopted the "13th Five-Year Plan" general higher education national planning textbooks or textbooks recommended by the Ministry of Education. In addition, teachers are required to actively edit or participate in the compilation of higher-level textbooks, who publish one textbook every year. Moreover, we should declare actively excellent textbooks for ordinary colleges and universities in Shaanxi.

\subsection{Faculty}

\subsubsection{Benchmark Famous Teachers' Standards}

The Shaanxi Provincial Department of Education has clearly stipulated the requirements for famous teachers, including teacher ethics, teaching ability and level, teaching echelon construction and contribution, scientific research and academic level, etc. To be a famous teacher, a teacher needs to have presided over major provincial education reform projects and important scientific research projects, published high-quality papers and publications, and instructed college students to participate in innovation and entrepreneurship competitions. We need to strive to improve ourselves with Shaanxi Province's famous teachers as our goal. 


\subsubsection{Expand Faculty Combined External Recruitment with Internal Training}

According to the First-class professional requirements of Shaanxi Province and the professional development goals of business administration, it is necessary to introduce 2 full-time doctoral teachers and 1 foreign teacher, and encourage young teachers to study for $\mathrm{PhD}$. Combining the current status of the expert team, it is necessary to introduce 3 industry experts and 1 university professor to form a team of academic consultants and experts, which possesses corporate executives and wellknown university professors.

\subsection{Research}

\subsubsection{Declare National Scientific Research Projects Actively}

First of all, professors should actively apply for national scientific research projects. Secondly, invite outstanding scholars from outside the school to share their scientific research experience, and to check and guide the application of the project, to increase the success rate of the project application. In addition, teachers with senior professional titles are required to declare national-level topics at least once a year until the declaration is successful.

\subsubsection{Establish Research Teams Relying on Research Institute}

We set up a small and medium-sized enterprise process management scientific research team and a digital operation scientific research team, relying on the Xi'an Institute of Quality Management. And we set up a service-oriented manufacturing research team, relying on the Service-oriented Manufacturing Research Institute. Gradually form a team advantage, and actively apply for the provincial scientific research team.

Actively carry out Industry-university-research projects through the research institute, do useful scientific research, gradually form a team advantage, and actively apply for a provincial-level scientific research team. In addition, teachers lead students to do scientific research and publish papers to enhance students' capabilities of scientific research and practical application.

\subsection{Practical Teaching and Industry-university Cooperation}

\subsubsection{Integrate Practical Teaching into the Professional Teaching System}

Business administration major firmly grasp the application-oriented school positioning during the construction, integrating practical teaching into the professional teaching system. In addition, we increase the proportion of professional practice teaching credits. More, students learn the ability to apply ERP and DingTalk digital platform through courses such as Business Thinking and Case Practice, Business Operation Simulation Practice, Digital Enterprise Management Practice. In addition to professional teaching, we have also introduced a large number of workshops and personalized development courses to integrate student growth, project practice, professional teaching and practical teaching, and promote students to apply what they have learned.

\subsubsection{Strengthen Industry-university Cooperation}

We will promote high-quality internships for student through in-depth cooperation with TOP companies. And cultivate students' core skills in employment through taking the joint laboratory as the carrier. Set up a course and laboratory training system with cooperative enterprises as the object of case analysis to increase students' understanding of business management practices. To increase employment opportunities for students, we establish cooperative relations with enterprises through professional internships and graduation internships. In addition, it will promote practical teaching and strengthen Industry-university cooperation through in-depth cooperation with cooperative enterprises.

\subsection{Local Internationalization}

\subsubsection{Normal 0peration of the Bilingual Experimental Class}

In accordance with the world's top business school curriculum system and EPAS international certification standards, a bilingual business administration experimental class is set up, with English 
teaching, cultural exploration, social research, mobile classrooms, etc., as well as a multicultural environment experience of living and learning with outstanding young people from around the world to train students to grow into a future international manager with excellent knowledge, cross-cultural understanding, and a sense of mission for a community with a shared future for mankind. Through the normal operation of the bilingual experimental class of business administration, students will broaden their international horizons, help them to enter international studies and obtain international employment.

\subsubsection{Build an International Curriculum Learning Platform}

With the help of the Internet platform and high-quality foreign curriculum resources, we can realize the integration of Chinese and Western cultures and build an international curriculum learning platform. First, students can learn high-quality public courses abroad. Second, students can connect with well-known foreign experts and scholars online through the Internet to hold online seminars or workshops. Third, international certificate courses can be introduced, such as CAPM, PMP, etc. Through the establishment of an international curriculum learning platform, students will broaden their international horizons, improve their international literacy, and help students enter international studies and employment.

\subsection{Quality Assurance}

\subsubsection{Ensure the Quality of Business Administration}

We improve the satisfaction of graduates and the recognition of employers, relying on the quality assurance team of Xi' an Quality Management Research Institute. First, build a professional internal quality monitoring mechanism, set clear quality requirements and process monitoring for each major teaching link, and be able to conduct quality evaluations. Second, establish external evaluation mechanisms such as graduate tracking feedback and employer satisfaction surveys to regularly evaluate the achievement of training goals. Finally, collect internal and external evaluation information and conduct comprehensive analysis, and use the analysis results for continuous improvement of professional construction.

\subsubsection{Form a Complete Quality Assurance System}

Build a complete quality assurance system throughout the entire process from students entering the school to their graduation to becoming alumni. With teaching management as the focus, strict management is carried out in terms of professional construction, curriculum construction, teaching links, teaching management rules and regulations. And, normalize the monitoring of teaching quality through the data collection and management platform of talent training work status, the teaching management information platform.

\section{Summary}

In the era of digital economy, business administration needs to carry out a comprehensive and systematic transformation in terms of talent training goals, curriculum settings, practical teaching systems, and teacher training. At the same time, it is also necessary to meet relevant requirements such as national standards and First-class professional construction requirements. Focusing on the changes of the times and the related requirements of professional construction, the business administration major of Xi'an Eurasia University has formulated the general development goal that to cultivate high-quality digital management talents for small and medium-sized enterprises, and build a digital operation application for enterprises in the western region guided by the employment standards of First-class enterprises. From these 8 aspects, the corresponding construction path is proposed, including admissions and employment, professional features, courses and teaching materials, faculty, research, practical teaching and Industry-university cooperation, local internationalization, and quality assurance. Our major will become a characteristic business administration major with regional characteristics, respected by peers, and influential in the world. 


\section{Acknowledgments}

2021 New Liberal Arts Research and Reform Practice Project of Shaanxi Province "Research and Practice on Optimization of Liberal Arts Major Structure in the New Era--Taking Xi'an Eurasia University as an Example";

2021 School-level Education and Teaching Reform Project of Xi'an Eurasia University "Innovation of Talent Training Mode for Applied Undergraduate Business Administration in the Digital Economy" (Project Number: 2021YB011).

\section{References}

[1] MENG Yi, CHEN Zhen, XU Chaojun, CHEN Qiulian. Research and Practice on the Training Model of New Business Talents in the Digital Economy Era [J]. Journal of Lingnan Normal University, 2021,42 (04): 24-31.

[2] HUANG Hanquan. Accelerate the Development of Modern Industrial System and Promote the Optimization and Upgrading of Economic System [N]. Economic Daily, 2020-11-23(001).

[3] Notice of the General Office of the Xi'an Municipal People's Government on Printing and Distributing the "Modern Industrial Layout Plan of Xi'an" [J]. Bulletin of the Xi'an Municipal People's Government, 2020 (11): 8-26.

[4] TIAN Zhilong, GAO Chuang. National Standards for Teaching Quality of Business Administration Majors: Why and What [J]. China University Teaching, 2019(03): 33-36+47.

[5] PAN Lianbo, WU Na. Innovation Research on Application Technical Practical Teaching of Economy and Management Specialty [J]. Laboratory Science, 2019, 22(02): 96-98.

[6] ZHAO Yong, ZHAO Xiaohui. Value Implication and Practical Principles of Collective Preparation for Ideological and Political Theory Courses[J]. Ideological \& Theoretical Education, 2020(08): 74-79. 